\author{
Zh. Amirkhanova ${ }^{1 *}$, R. Bodeeva ${ }^{1}$, S. Akhmetova ${ }^{2}$, \\ A. Tuyakova $^{3}$, S. Kozhakhmetov ${ }^{3}$, A. Kushugulova ${ }^{3}$ \\ ${ }^{l}$ Karaganda University of the name of academician E.A. Buketov, Kazakhstan; \\ ${ }^{2}$ Medical University of Karaganda, Kazakhstan; \\ ${ }^{3}$ Laboratory of human microbiome and longevity, Center for Life Sciences, «National Laboratory Astana» Ltd, Nazarbayev \\ University, Nur-Sultan, Kazakhstan \\ *Corresponding author: janerkeamir@mail.ru
}

\title{
MALDI mass spectrometry for identification lactic acid bacilli isolated from lactic acid products produced in the Karaganda region
}

\begin{abstract}
At present the traditional methods of identifying microorganisms are replaced by express methods, the mass spectrometric method using MALDI-TOF MS allows to reliably identify a variety of microorganisms in a short time, which is an indisputable advantage in work and allows to quickly identify many microorganisms in quickly. Classical methods for the identification of lactic acid bacteria based on their cultivation require a long time for their implementation. The advent of matrix laser desorption ionization time-of-flight mass spectrometry (MALDI-TOF MS) technology made significant changes in the workflows for the study of lactic acid bacteria, unmatched in speed characteristics. This article presents the study of the morphological, cultural properties, acid-forming ability, antibiotic sensitivity lactic acid bacteria of isolated from ... products (ayran, koumiss, ashykan kozhe, kurt, suzbe, cottage cheese) produced in different districts of the Karaganda region. The species identification of the isolated strains of lactic acid bacteria was carried out using a MALDI-TOF mass spectrometer. The studies carried out on cultural and morphological characters indicate that they belong to the genus Lactobacillus, Lacticaseibacillus, Lactiplantibacillus, Limosilactobacillus. As a result of identification on the mass spectrometer of the presented samples L. acidophilus (2 strains), L. delbrueckii subsp. bulgaricum (2 strains), L. rhamnosus (7 strains), L. plantarum (2 strains), L. paracasei (11 strains), L. fermentum (2 strains) were revealed. According to the Score values, the results indicate the accuracy of the identification.
\end{abstract}

Keywords: lactic acid bacilli, strain, identification, cultivation, mass spectrometry (MALDI-TOF MS), dairy products, morphology, nutrient medium.

\section{Introduction}

A significant disadvantage of the widely used traditional microbiological methods is the long time to obtain the result, which is due to the physiology of microorganisms that requires time for their growth. Modern microbiology requires new fast and accurate methods for the identification of microorganisms.

The advent of matrix laser desorption ionization time-of-flight mass spectrometry technology has made significant changes in the workflow of microbiology laboratories, virtually unmatched in the speed and accuracy of microbial identification. This method, which is gradually becoming the standard for modern laboratories, makes it possible to reduce the identification time of pure cultures to several minutes [1].

The method is based on the extraction of peptides and proteins from cells of microorganisms and works according to the principle (molecular «fingerprint»), which is compared with the reference spectra in the MALDI bio typer database [2].

The MALDI TOF mass spectrometry method allows not only to identify a microorganism but also, in some cases, obtain a unique set of ribosomal proteins (fingerprints) for each of the strains under study, which opens up great opportunities and prospects for studying strain characteristics [3].

Bacteria of the genus Lactobacillus has always attracted attention of scientists and researchers around the world due to its great practical value.

The genus Lactobacillus includes more than 261 species (as of March 2020), which are very diverse at the phenotypic and genotypic levels. The genus was reclassified based on phylogenetic studies of the main genome, taking into account the physiological and ecological criteria: the corrected genus Lactobacillus was retained and 23 new genera were added [4].

Classical methods for the identification of lactic acid bacilli based on their cultivation require a long time for their implementation. The advent of matrix laser desorption ionization time-of-flight mass spec- 
trometry (MALDI-TOF MS) technology made significant changes in the workflows for the study of lactic acid bacilli, unmatched in speed characteristics.

Objective: identification and study of the morphological and cultural properties, acid formation activityand the resistance to antimicrobial preparation of lactic acid bacilli isolated from lactic acid products Karaganda region by time-of-flight MALDI-TOF mass spectrometry (in vitro study).

\section{Methodology}

63 samples of lactic acid products were used for the study (ayran, koumiss, ashykankozhe, kurt, suzbe, cottage cheese) produced in different areas of the Karaganda region.

Sampling: sampling was carried out in accordance with the rules of asepsis. Before analyzing samples for the presence of probiotic cultures liquid dairy products (ayran, koumiss, ashykan kozhe) were stirred in a circular motion, avoiding active shaking to prevent air saturation. Cottage cheese, suzbe - were mixed by shaking.

- liquid dairy products were taken with a sterile pipette $(10 \mathrm{ml})$ and placed in sterile test tubes.

- a pasty dairy product (suzbe) was taken with a sterile spatula $(10 \mathrm{~g})$ and placed into sterile test tubes.

- $10 \mathrm{~g}$ of kurt and cottage cheese were weighed on a Petri dish, transferred to a sterile porcelain mortar with a pestle, and thoroughly ground [5-6].

Study of morpho-cultural properties, mobility, and catalase test: Before sowing, a tenfold dilution was prepared from each product in sterile saline, followed by sowing on Petri dishes with agar MRS medium. The Petri dishes were cultured at $37^{\circ} \mathrm{C}$ for 2 days in anaerobic conditions.

After Petri dishes incubation, 42 strains of lactic acid bacilli were isolated from the milk product (ayran, koumiss, ashykankozhe, kurt, suzbe, cottage cheese), of which 26 isolated colonies were typical of lactic acid bacilli, microscoped (Gram stain) and seeded on MRS broth.

After 2 days of incubation control, smears were made from all tubes with broth, after which the isolate individual colonies by ten-fold dilution method, followed by seeding on Petri dishes with agarised MRS medium. Crops were incubated in anaerobic conditions at $37 \pm 1^{\circ} \mathrm{C}$ temperature for 48 hours [7-8].

After incubation, isolated colonies were determined by relation to Gram stain, mobility, presence of catalase and identified on MALDI BioTyper.

To determine the ratio of the isolated strains to Gram stain, smears were prepared from the colonies, stained according to the Gram method and microscoped. We took photos using a ToupcamTM USB digital eyepiece camera Industrial digital camera, 14 megapixels.

Catalase activity test: the catalase activity of the cultures was determined on the ability of catalase to decompose hydrogen peroxide with the release of gas bubbles. The reaction was set up with a daily culture cooled to room temperature on a sterile glass slide. An isolated colony taken from the surface of the nutrient medium was ground on glass and a drop of $3 \%$ hydrogen peroxide solution was applied with a pipette. If after 30-60 s gas bubbles appear on the glass, then the reaction results are considered positive. A control sample was placed in parallel. The mobility of the isolated cultures was determined by «the crushed drop» [9].

The grown crops were identified using the MALDI BioTyper. The samples were prepared as follows: a fresh single colony was directly transferred onto a polished steel MSP 96 target (Bruker Daltonik) and dried; coated with $1 \mu 1$ of a saturated solution of a-cyano-4-hydroxy-cinnamic acid (HCCA) matrix solution in $50 \%$ acetonitrile- $2.5 \%$ trifluoroacetic acid (Bruker Daltonik) and dried at room temperature, after that the sample was subjected to analysis of the bacteria protein using MALDI-TOF MS system [10].

The identification reliability criteria were judged by the following score values: $2,300-3,000-$ highly probable species identification; 2,000-2,299 — reliable genus identification, probable species identification; $1,700-1,999$ - probable identification of the genus; $0-1.699$ - identification failed.

Determination of acid formation activity. Two tubes of each culture were removed and put into a refrigerator for rapid cooling to prevent further acid production. Then, $10 \mathrm{ml}$ of culture liquid was added to glass flasks, and phenolphthalein was added as an indicator 1 drop.

The total acidity was determined by titration of decinormal alkali $\mathrm{NaOH}$, which was added dropwise from the burette to the retorts with the poured culture liquid until a stable pink stain appeared. The amount of decinormal alkali that was used for titration corresponds to the amount of decinormal acid produced in $10 \mathrm{ml}$ of culture liquid [11]. 
Data of acid formation activity, expressed in degrees Turner $/{ }^{\circ} \mathrm{T} /$, was calculated by the formula:

$$
\circ \mathrm{T}=\mathrm{a} \times \mathrm{k} \times 10
$$

where $\mathrm{a}$ is the number of milliliters of $0,1 \mathrm{M}$ caustic soda solution to be titrated; $\mathrm{k}$ is a correction to the titer of $0,1 \mathrm{M}$ caustic soda solution; 10 is a correction factor for the mass of the analyzed sample.

The sensitivity of probiotic bacteria to antibiotics was determined by disk-diffusion test. From the test cultures, the suspensions conforming to the optical turbidity standard of 5 units (with a microbial body content of about $1,5 \times 10^{8} \mathrm{CFU} / \mathrm{ml}$ ) were prepared, $1 \mathrm{~cm}^{3}$ of the culture suspension was applied to each agar medium dish, uniformly distributed over the surface by lawn method and slightly dried in laminar flow. Further, the antibiotic discs of 5 pieces were applied to the surface of the nutrient medium seeded with a suspension of lactic acid bacilli cells. Inoculated plates with discs were incubated at $37 \pm 1{ }^{\circ} \mathrm{C}$ for $48 \mathrm{~h}$. The antibiotic graph was formed by the diameter of the growth retardation zone of microorganisms. The study was performed in triplicate and the results were expressed as arithmetic mean.

\section{Results and Discussion}

The studies carried out on cultural and morphological characters indicate their belonging to the genus Lactobacillus, Lacticaseibacillus, Lactiplantibacillus, Limosilactobacillus. All isolated strains are grampositive rods, cells are located singly, in pairs, in the form of a chain, motionless, spores do not form (Fig. 1, 2), catalase-negative (lactic acid bacilli do not have catalase, therefore, no gas formation was observed in the sample with hydrogen peroxide). Colony morphology (Figure 3, 4) of isolated strains of lactic acid bacilli are identified on solid nutrient medium MRS agar-1.

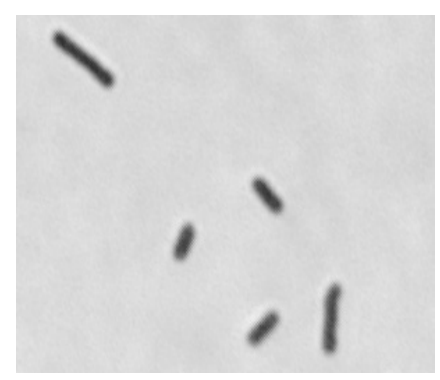

Figure 1. The microscopic drawing (100x) of the isolated strain L.paracasei -28

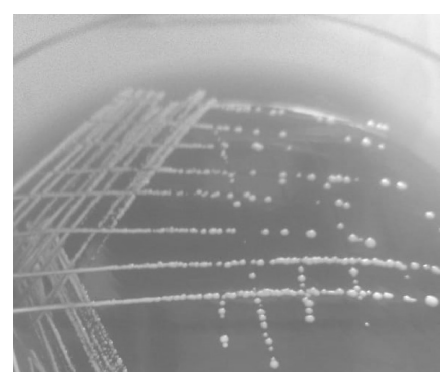

Figure 3. Morphology colonies of the isolated strain L.paracasei -28

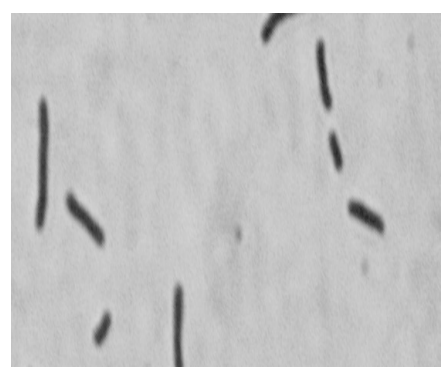

Figure 2. The microscopic drawing (100x) of the isolated strain L. fermentum -18

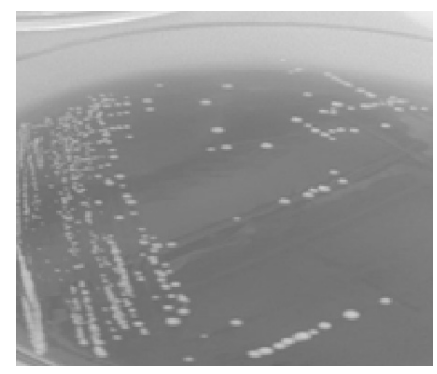

Figure 4. Morphology colonies of the isolated strain L. fermentum -18

As a result of identification on the mass spectrometer of the presented samples it was L. acidophilus (2 strains), L.delbrueckiisubsp. bulgaricum (2 strains), L.rhamnosus (7 strains), L. plantarum (2 strains), L.paracasei (11 strains), L. fermentum (2 strains) - only 26 strains were revealed.

According to the Score values, the results indicate the accuracy of identification: Score values 2.300-3.000 are observed in 7 strains; Score values 2.000-2.299 are recorded in 15 strains; Score values $1.700-1.999$ - in 4 strains.

Acid formation activity is a normalized indicator of biological activity of lactic acid bacilli and accordingly a criterion for selection of lactic acid bacilli strains with high-active probiotic properties. The results obtained in the study (Figure 5,6) show good acid-forming ability in most isolated lactic acid bacilli 
strains. Strains of lactic acid bacilli, titrated acidity of which varies within $20-80^{\circ} \mathrm{T}$ are considered inactive, $90-110^{\circ} \mathrm{T}-$ average activity, and $120^{\circ} \mathrm{T}$ and higher are considered highly active.

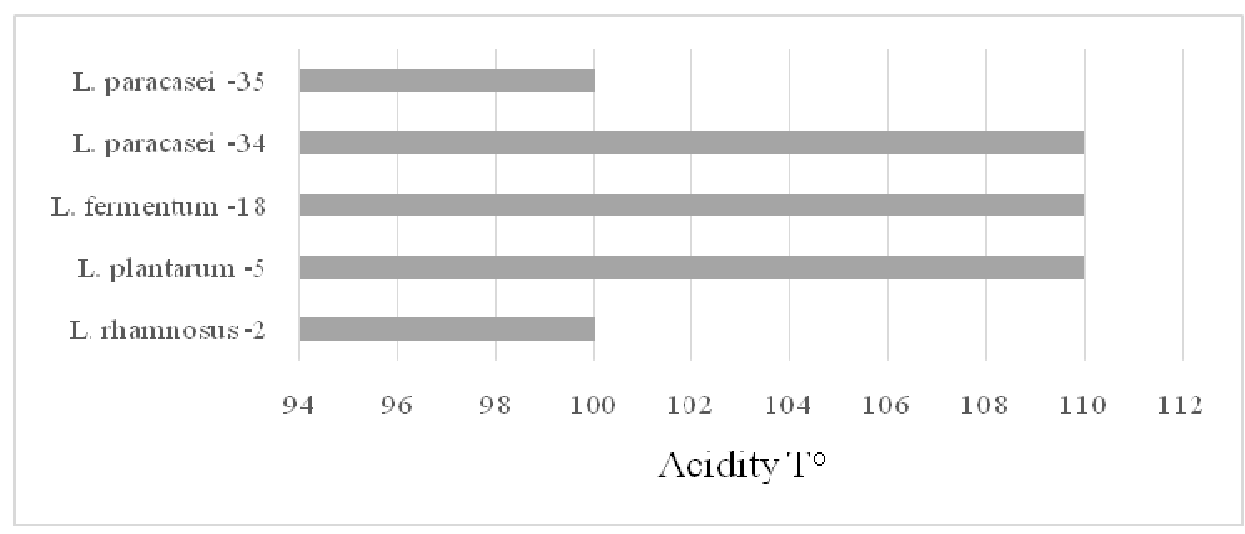

Figure 5. Acid formation activity of lactic acid bacilli selected strains — average activity

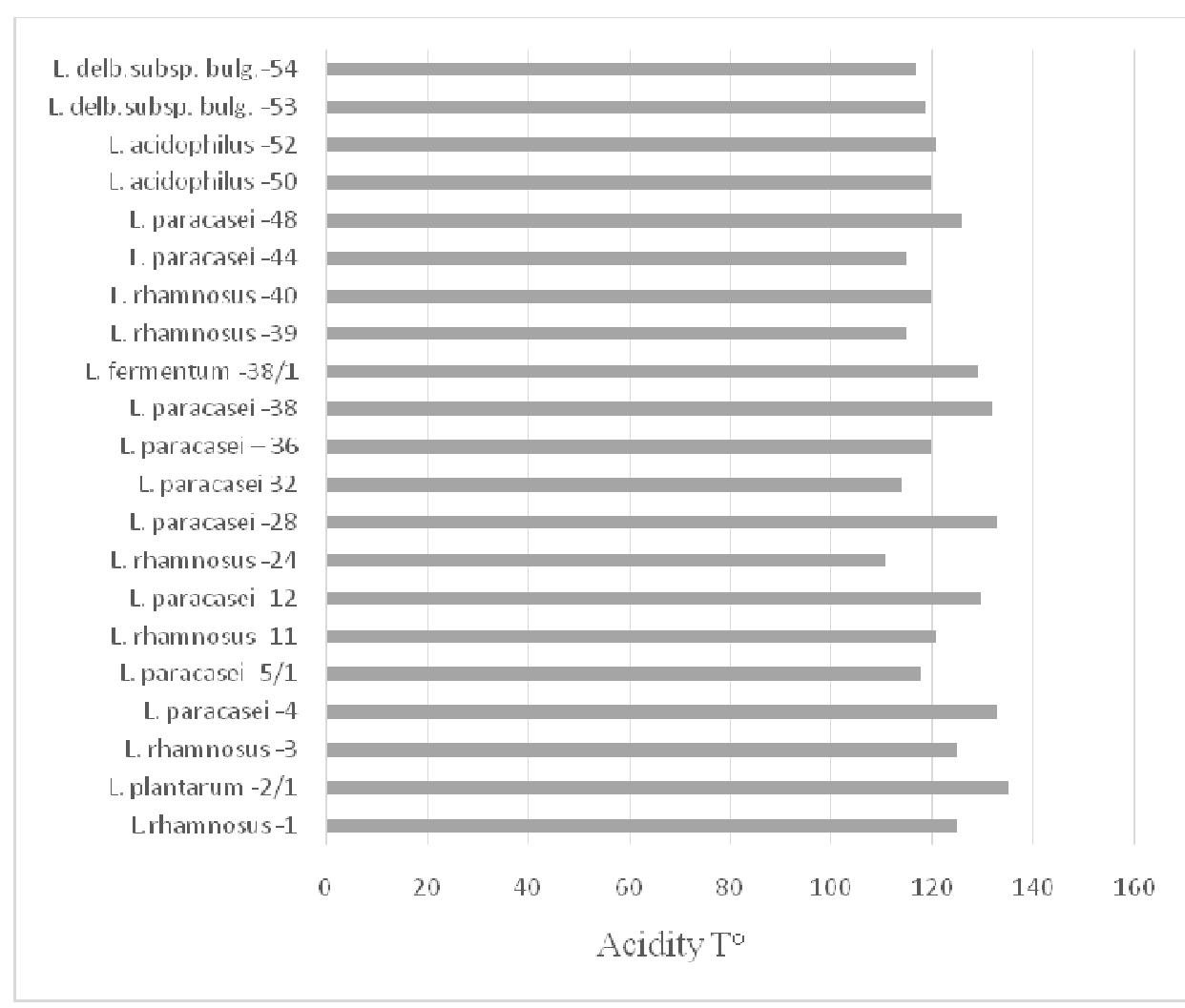

Figure 6. Acid formation activity of lactic acid bacilli selected strains — high activity

The resistance of bacteria to antimicrobial preparation is a characteristic feature of a particular strain of the microorganism and this should be taken into account when selecting cultures, products and preparations with probiotic properties used in biotechnology. In this regard, we have conducted studies to determine the spectrum of antibiotic resistance of isolated strains of lactic acid bacilli, to various most common antibiotics in medical practice.

The study found that 10 strains L.paracasei, 5 strains L. rhamnosus, 2 strains L. fermentum, 2 strains L. acidophilus, 1 strains $L$. delbr. subsp. bulg. are metronidazole $(5 \mu \mathrm{g} / \mathrm{disc})$ resistant the following strains are sensitive to antibiotic metronidazole L. paracasei - $36(16 \mathrm{~mm})$, L. plantarum $-2 / 1-(8 \mathrm{~mm})$, L. plantarum -5-(10 mm), L. rhamnosus $-24-(11 \mathrm{~mm})$, L. plantarum $-2 / 1-(8 \mathrm{~mm})$, L. delbr. subsp. bulg. $-53-(18 \mathrm{~mm}) ; 9$ strains L.paracasei, 5 strains L. rhamnosus, 2 strains L. fermentum, 1 strains L. acidophilus, 1 strains $L$. delbr. subsp. bulg. showed resistance to colistin $(25 \mu \mathrm{g} / \mathrm{disc})$, the following strains are sensitive to antibiotic colistin L. paracasei - $4(8 \mathrm{~mm})$, L. paracasei $-36(10 \mathrm{~mm})$, L. plantarum $-2 / 1-(9 \mathrm{~mm})$, 
L. plantarum -5- $(7 \mathrm{~mm})$, L. rhamnosus -24 - (23 mm), L. plantarum -2/1- $(9 \mathrm{~mm})$, L. acidophilus $-50-$ (24 mm), L. delbr. subsp. bulg. $-54-(12 \mathrm{~mm})$.

Resistance was observed in 4 strains L.paracasei, 1 strains L. rhamnosus, 1 strains L. acidophilus to cefuroxime $(30 \mu \mathrm{g} / \mathrm{disc})$, sensitive to antibiotic cefuroxime the following strains L. paracasei $-4(23 \mathrm{~mm})$, L. paracasei $-5 / 1-(23 \mathrm{~mm})$, L. paracasei $-12-(31 \mathrm{~mm})$, L. paracasei $-36(33 \mathrm{~mm})$, L. paracasei $-38-$ $(19 \mathrm{~mm})$, L. paracasei $-44-(33 \mathrm{~mm})$, L. paracasei $-48-(22 \mathrm{~mm})$, L. rhamnosus $-1-(33 \mathrm{~mm})$, L. rhamnosus $-2-$ $(23 \mathrm{~mm})$, L. plantarum -2/1-(17 mm), L. rhamnosus -3-(17 mm), L. plantarum -5-(20 mm), L. rhamnosus $11-(30 \mathrm{~mm})$, L. fermentum -18-(18 mm), L. rhamnosus $-24-(31 \mathrm{~mm})$, L. rhamnosus $-40-(45 \mathrm{~mm})$, L. plantarum -2/1-(17 mm), L. fermentum -38/1-(27 mm), L. acidophilus -50-(34 mm), L. acidophilus -52(17 mm), L. delbr. subsp. bulg. -53-(23 mm), L. delbr. subsp. bulg. $-54-(33 \mathrm{~mm})$.

Most strains of lactic acid bacilli were sensitive to the following antibiotics (Figure 7,8): levomycetin $(10 \mu \mathrm{g} / \mathrm{disc})$, amoxyclav $(10 \mu \mathrm{g} / \mathrm{disc})$, benzylpenicillin $(10 \mu \mathrm{g} / \mathrm{disc})$, gentamycin $(10 \mu \mathrm{g} / \mathrm{disc})$, tetracycline (10 $\mu \mathrm{g} / \mathrm{disc})$, clindamycin $(10 \mu \mathrm{g} / \mathrm{disc})$, ciprofloxacin $(30 \mu \mathrm{g} / \mathrm{disc})$.

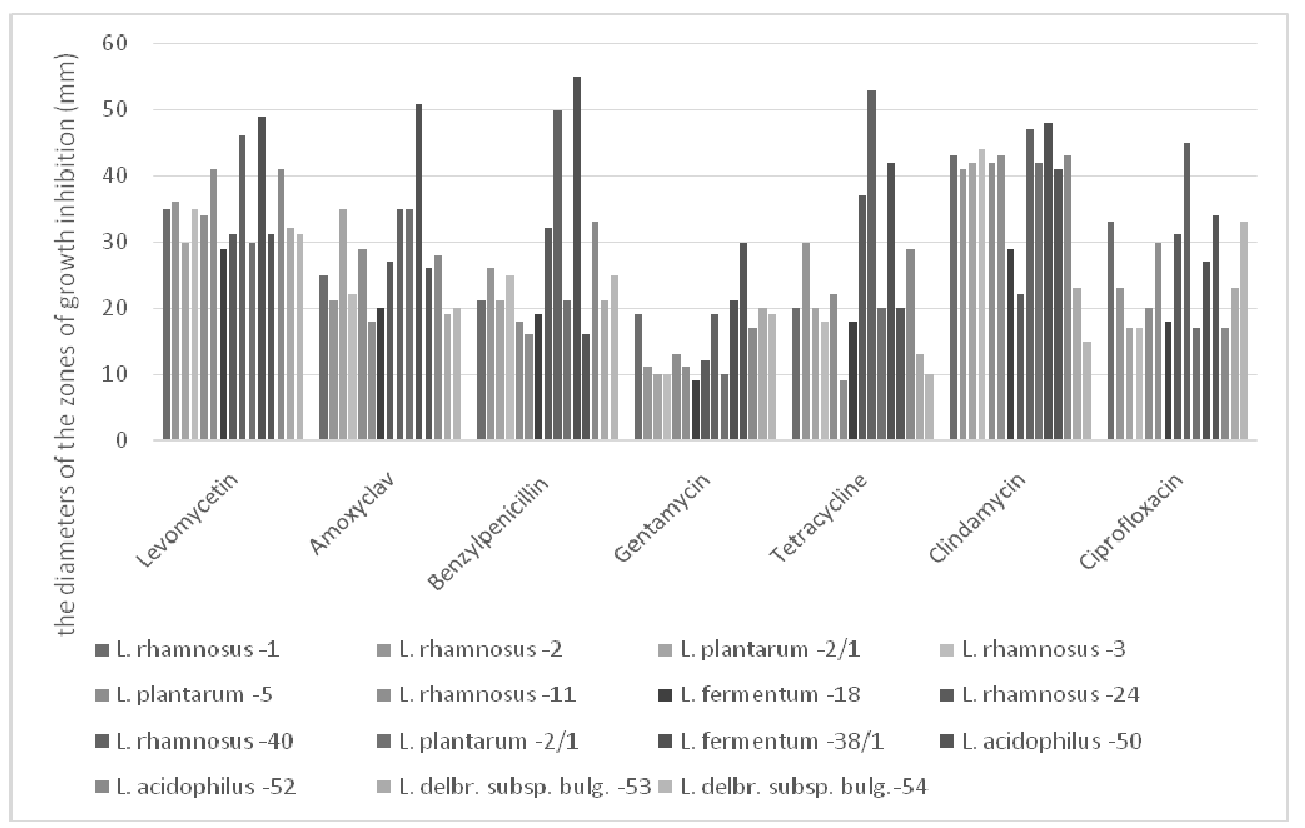

Figure 7. Antibiotic sensitivity of strains L. rhamnosus, L. plantarum, L. fermentum, L. acidophilus, L. delbr. subsp. bulg.

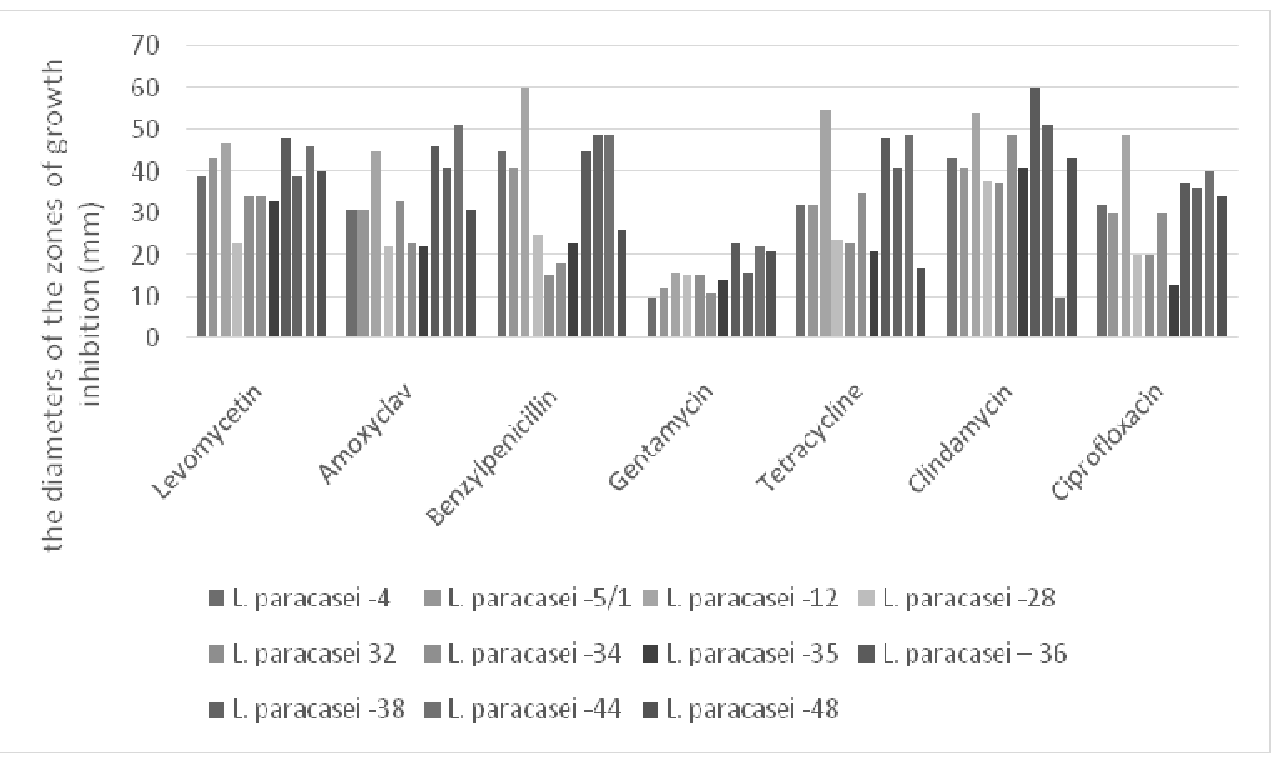

Figure 8. Antibiotic sensitivity of strains L.paracasei 


\section{Conclusions}

As a result of the studies carried out it can be concluded that it is impossible to judge with confidence the species homogeneity or heterogeneity of the culture by morpho-cultural characters, since the shape and size of microbial cells, the shape of the lactic acid bacilli colony varies markedly. Factors such as culture conditions, bacterial growth phases, and others inhibit the work of the researcher. Our research has shown that using MALDI-TOF-MS analyzes has become a part of the daily practical work of a microbiologist in identifying lactic acid bacilli, and even surpasses the (classical) methods of microbiological identification previously used by us in terms of speed and reliability.

According to literary data [12], in vitro lactic acid bacilli sensitivity tests are still poorly standardized. The evaluation of antibiotic sensitivity of these bacteria is extremely difficult, because the size of the zones recommended for other bacteria are not applicable to them. To these reasons are added specific conditions of cultivation: enriched medium, complex composition of the atmosphere, prolonged incubation.

Domestic microbiologists K.Kh. Almagambetov, I.S. Savitskaya et.al. do not give the clear criteria for the classification of strains of lactic acid bacilli to sensitive or resistant [13]. Therefore, empirical concentrations in the antibiotic disc ( $\mu \mathrm{g} / \mathrm{disc})$ that delayed the growth of at least one of the strains studied were selected as boundary minimum inhibitory concentrations (MIC).

\section{References}

1 Попов Д.А. Применение метода MALDI-TOF MS в современной микробиологической лаборатории / Д.А. Попов, С.Т. Овсеенко, Т.Ю. Вострикова // Спецвып. ЛАБОРАТОРИЯ ЛПУ. — 2016. — № 8. — С. 53-56.

2 Лавриненко A.В. Использование методов MALDI-TOF масс-спектрометрии и питательной среды Chromagar Candida для идентификации грибов рода Candida / А.В. Лавриненко, И.С. Азизов, С.И. Колесниченко // Успехи мед. микологии. 2016. - C. 74, 75 .

3 Точилина А.Г. Изучение биологических свойств штаммов рода Lactobacillus / А.Г. Точилина, И.В. Белова, И.В. Соловьева, Н.А. Новикова, Т.П. Иванова, В.А. Жирнов // Современные проблемы науки и образования. - 2015. № 5. - C. 462-468.

4 Zheng J. A taxonomic note on the genus Lactobacillus: Description of 23 novel genera, emended description of the genus Lactobacillus Beijerinck 1901, and union of Lactobacillaceae and Leuconostocaceae» / J. Zheng, S. Wittouck, E. Salvetti, C. Franz, H. Harris, P. Mattarelli, P. W. O’Toole, B. Vandamme, J. Walter, K. Watanabe, S. Wuyts, G.E. Felis, M.G. Gänzle, S. Lebeer // International Journal of Systematic and Evolutionary Microbiology. — 2020. — Vol. 70. - P. 2782-2858.

5 Межгосударственный стандарт. Молоко и молочная продукция. Методы микробиологического анализа: ГОСТ 32901-2014. - М.: Стандартинформ Российской Федерации, 2014. - 56 с.

6 ГОСТ Р 56139-2014. Продукты пищевые специализированные и функциональные. Методы определения и подсчета пробиотических микроорганизмов. - М.: Стандартинформ Российской Федерации, 2016. - 25 с.

7 Лабинская А.С. Общая и санитарная микробиология с техникой микробиологических исследований / А.С. Лабинская, Л.П. Блинкова, А.С. Ещина. - М.: Медицина, 2004. — 575 с.

8 Яруллина Д.Р. Бактерии рода Lactobacillus: общая характеристика и методы работы с ними: учеб.-метод. пос. / Д.Р. Яруллина, Р.Ф. Фахруллин. — Казань: Казан. ун-т, 2014. — 51 с.

9 Сбойчаков В.Б. Микробиология, вирусология и иммунология: руководство к лабораторным занятиям: учеб. пос. / В.Б. Сбойчаков, М.М. Карапац. - М.: ГЭОТАР-Медиа, 2014. — 320 с.: ил.

10 Schulthess B. Evaluation of the Bruker MALDI Biotyper for identification of Gram-positive rods: development of a diagnostic algorithm for the clinical laboratory / B. Schulthess, G.V. Bloemberg, R. Zbinden, E.C. Böttger, M. Hombach // Journal of clinical microbiology. — 2014. — Vol. 52, № 4. - P. 1089-1097.

11 Общая фармакопейная статья «Определение специфической активности пробиотиков: ОФС. 1.7.2.0009.15».

12 Багдасарян А.С. Антибиотикоустойчивость пробиотических культур, входящих в состав синбиотиков / А.С. Багдасарян, Э.С. Токаев, Е.А. Некросав, Е.А. Олейник // Изв. вузов. Пищевая технология. — 2011. — № 2, 3. — С. $102-$ 104.

13 Савицкая И.С. Антибиотикорезистентность лактобацилл-пробиотиков / И.С. Савицкая, А.А. Жубанова, А.С. Кистаубаева, А.Б. Болекбаева // Вестн. Казах. нац. ун-та. Сер. биол. — 2012. — Т. 56, № 4. — С. 222-227. 
Ж. Амирханова, Р. Бодеева, С. Ахметова, А. Туякова, С. Кожахметов, А. Кушугулова

\section{Қарағанды облысында өндірілетін сүтқышқылды өнімдерден бөлініп алынған сүтқышқылды бациллаларды идентификациялау үшін малди масс-спектрометрияны қолдану}

Қазіргі уақытта микроорганизмдерді идентификациялаудың дәстүрлі әдістерінің орнына жеделәдістер қолданылуда. MALDI-TOF MS көмегімен масс-спектрометриялық әдісті қолдану қысқа мерзімде әртүрлі микроорганизмдерді нақты түрде идентификациялауға мүмкіндік береді. Сүтқышқылды бактерияларды идентификациялау үшін қолданылатын классикалық әдістер ұзақ уақытты қажет етеді. Матрицалық лазерлік десорбциялы ионизациялық белсендірілген массспектрометрия (MALDI-TOF MS) технологиясының пайда болуы сүтқышқылды бактерияларды зерттеу бойынша жұмыс процестеріне елеулі өзгерістер енгізді. Мақалада Қарағанды облысының әртүрлі аудандарында өндірілетін сүт қышқылды өнімдерден (айран, қымыз, ашыған көже, құрт, сүзбе, ірімшік) бөлініп алынған сүтқышқылды бациллалардың морфологиялық, дақылдық қасиеттері, қышқыл түзу қабілеті, антибиотиктерге сезімталдығының зерттеулері қарастырылған. Бөлініп алынған сүтқышқылды бациллалардың штамдарының түрлік тиістілігін идентификациялау массспектрометрдің MALDI-TOF көмегімен жүргізілді. Морфологиялық және дақылдық белгілері бойынша жүргізілген зерттеулер олардың Lactobacillus, Lacticaseibacillus, Lactiplantibacillus, Limosilactobacillus туыстастығына жататындығын көрсетті. Зерттеуге алынған үлгілерден бөлініп алынған сүтқышқылды бациллаларды масс-спектрометрде идентификациялау нәтижесінде: $L$. acidophilus (2 штамм), L.delbrueckiisub sp. bulgaricum (2 штамм), L. rhamnosus (7 штамм), L. plantarum (2 штамм), L. paracasei (11 штамм), L. fermentum (2 штамм) анықталды. Score values мәндеріне сәйкес алынған нәтижелер идентификацияның дәлдігін көрсетті.

Кілт сөздер: сүтқышқылды бациллалар, штамм, идентификация, дақылдандыру, масс-спектрометрия (MALDI-TOF MS), сүтқышқылды өнімдер, морфология, қоректік орта.

Ж. Амирханова, Р. Бодеева, С. Ахметова, А. Туякова, С. Кожахметов, А. Кушугулова

\section{МАЛДИ масс-спектрометрия для идентификации молочнокислых палочек, выделенных из молочнокислых продуктов, производимых в Карагандинской области}

В настоящее время классические методы идентификации микроорганизмов заменяют экспрессметоды. Масс-спектрометрический метод при помощи MALDI-TOF MS позволяет в краткие сроки достоверно идентифицировать разнообразные микроорганизмы, что является неоспоримым преимуществом в работе и позволяет быстро идентифицировать множество микроорганизмов за короткое время. Классические методы идентификации молочнокислых бактерий, основанные на их культивировании, требуют длительного времени для своей реализации. Появление матричной лазерной десорбционной ионизационной времяпролетной масс-спектрометрии (MALDI-TOF MS) внесло большие изменения в рабочие процессы по исследованию молочнокислых бактерий, не имея себе равных по скоростным характеристикам. В статье представлено изучение морфологических культуральных свойств, а также кислотообразующей способности и антибиотикочувствительности молочнокислых палочек, выделенных из молочнокислых продуктов (айран, кумыс, ашыган коже, курт, сузбе, творог), производимых в разных районах Карагандинской области. Определение видовой принадлежности выделенных штаммов молочнокислых палочек проводили с использованием MALDI-TOF массспектрометра. Проведенные исследования по культурально-морфологическим признакам свидетельствуют о принадлежности их к роду Lactobacillus, Lacticaseibacillus, Lactiplantibacillus, Limosilactobacillus. В результате идентификации на масс-спектрометре в представленных образцах было выявлено: L. acidophilus (2 штамма), L. delbrueckiisub sp. bulgaricum (2), L. rhamnosus (7), L. plantarum (2), L. paracasei (11), L. fermentum (2). В соответствии со значением Score values результаты свидетельствуют о точности идентификации.

Ключевые слова: молочнокислые палочки, штамм, идентификация, культивирование, массспектрометрия (MALDI-TOF MS), молочнокислые продукты, морфология, питательная среда. 


\section{References}

1 Popov, D.A., Ovseenko, S.T., \& Vostrikova, T.Yu. (2016). Primenenie metoda MALDI-TOF MS v sovremennoi mikrobiologicheskoi laboratorii [Application of the MALDI-TOF MS method in a modern microbiological laboratory]. Spetsvypusk LABORATORIIA LPU - Special LABORATORY to the clinic, 8, 53-56 [in Russian].

2 Lavrinenko, A.V., Azizov, I.S. \& Kolesnichenko, S.I. (2016). Ispolzovanie metodov MALDI-TOF mass-spektrometrii i pitatelnoi sredy Chamada Candida dlia identifikatsii gribov roda Candida [Using the methods of MALDI-TOF mass spectrometry and nourishing environment Chamada Candida for identification of fungi of the genus Candida]. Uspekhi meditsinskoi mikologii Advances in medical mycology, 74, 75 [in Russian].

3 Tochilina, A.G., Belova, I.V., Soloveva, I.V., Novikova, N.A., Ivanova, T.P. \& Zhirnov, V.A. (2015). Izuchenie biologicheskikh svoistv shtammov roda Lactobacillus [Study of biological properties of Lactobacillus strains]. Sovremennye problemy nauki i obrazovaniia - Modern problems of science and education, 5 [in Russian].

4 Zheng, J., Wittouck, S., Salvetti, E., Franz, C., Harris, H., Mattarelli, P., O’Toole, P. W., Vandamme, B.P., Walter, J., Watanabe, K., Wuyts, S., Felis, G.E., Gänzle, M.G. \& Lebeer S. (2020). A taxonomic note on the genus Lactobacillus: Description of 23 novel genera, emended description of the genus Lactobacillus Beijerinck 1901, and union of Lactobacillaceae and Leuconostocaceae. International Journal of Systematic and Evolutionary Microbiology, 70, 2782-2858.

5 Mezhgosudarstvennyi standart. Moloko i molochnaia produktsiia. Metody mikrobiologicheskogo analiza [Interstate standard milk and dairy products. Methods of microbiological analysis]. (2014) [in Russian].

6 HOST R-56139-2014. Produkty pishchevye spetsializirovannye $i$ funktsionalnye. Metody opredeleniia $i$ podscheta probioticheskikh mikroorganizmov [Specialized and functional food products. Methods for determining and counting probiotic microorganisms]. (2016) [in Russian].

7 Labinskaia, A.S., Blinkova, L.P. \& Eshchina, A.S. (2004). Obshchaia i sanitarnaia mikrobiologiia s tekhnikoi mikrobiologicheskikh issledovanii [General and sanitary microbiology with microbiological research techniques]. Moscow: Meditsina [in Russian].

8 Yarullina, D.R. \& Fakhrullin, R.F. (2014). Bakterii roda Lactobacillus: obshchaia kharakteristika $i$ metody raboty s nimi [Bacteria of the genus Lactobacillus: general characteristics and methods of working with them]. Kazan: Izdatelstvo Kazanskogo universiteta [in Russian].

9 Sboichakov, V.B. \& Karapats, M.M. (2014). Mikrobiologiia, virusologiia i immunologiia: rukovodstvo $k$ laboratornym zaniatiiam [Microbiology, Virology and Immunology: a guide to laboratory classes]. Mocow: GEOTAR-Media [in Russian].

10 Schulthess, B., Bloemberg, G.V., Zbinden, R., Böttger, E.C. \& Hombach, M. (2014). Evaluation of the Bruker MALDI Biotyper for identification of Gram-positive rods: development of a diagnostic algorithm for the clinical laboratory. Journal of clinical microbiology, 52, 4, 1089-1097.

11 Obshchaia farmakopeinaia statia «Opredelenie spetsificheskoi aktivnosti probiotikov» [General Pharmacopoeia article «Determination of specific activity of probiotics»]. (2015) [in Russian].

12 Bagdasarjan, A.S., Tokaev, Je.S., Nekrosav, E.A. \& Olejnik, E.A. (2011). Antibiotikoustoichivost probioticheskikh kultur, vkhodiashchikh v sostav sinbiotikov [Antibiotic resistance of probiotic cultures included in the synbiotic]. Izvestiia vuzov. Pishchevaia tekhnologiia - News of institutes of higher education. Food technology, 2-3, 102-104 [in Russian].

13 Savickaja, I.S., Zhubanova, A.A., Kistaubaeva, A.S. \& Bolekbaeva, A.B. (2012). Antibiotikorezistentnost laktobatsillprobiotikov [Antibiotic resistance of lactobacilli-probiotics]. Vestnik Kazakhskogo natsionalnogo universiteta. Seriia biologicheskaia - Bulletin of KazNU. Biology series, 56, 4, 222-227 [in Russian]. 